\title{
Analysis and Evaluation of Chinese Cross-Border Electricity Supplier Logistics
}

\author{
Wei Wang \\ Beijing Wuzi University, Beijing, China \\ Email: wangwei199304@126.com
}

Received 30 June 2016; accepted 19 July 2016; published 22 July 2016

Copyright ( 2016 by author and Scientific Research Publishing Inc.

This work is licensed under the Creative Commons Attribution International License (CC BY). http://creativecommons.org/licenses/by/4.0/

(c) (†) Open Access

\begin{abstract}
With economic development, China has become the world's second largest economy center, while the economic and technological development of high-speed, cross-border electricity supplier is also developing. Cross-border electricity supplier is an important way for China to go out of the product. Analysis of this paper was for cross-border electricity supplier in the development of China's current situation, the problem of Chinese enterprises and foreign enterprises for crossborder electricity supplier if cooperation was on Game Theory, and Fuzzy Comprehensive crossborder electricity supplier logistics took the form of a questionnaire survey conducted Chinese cross-border electricity supplier evaluation, and ultimately concluded that business cooperation between nations was necessary to choose. It is the optimal solution of mutual profit to put forward China cross-border electricity suppliers should be the suggestions for further improvement in the logistics problem, government investment, exchange of information and so on.
\end{abstract}

\section{Keywords}

Cross-Border Electricity Supplier Logistics, China, Game Theory

\section{Introduction}

With the introduction of the new Chinese policies and government support, China has further developed crossborder electricity suppliers and annual of most consumers buy goods in other countries. This phenomenon makes Chinese imports increased to deal size but for China's economic loss is relatively large, and the majority of foreign capital flows. For many foreign places, the "Amoy China" is also more popular recently, a purchase many consumers will choose to buy foreign products in China. Because Chinese products tend to have lighter items; the appearance of new goods is beautiful and other characteristics. The most important is that China's products are cheap. In order to promote the development of global economic, the Chinese government decide to 
reduce customs duties in the future. Foreign people buy more Chinese products than before, and it will further strengthen the Chinese exports and it can bring profits opportunities. It also can provide a strong guarantee for China's cross-border electricity supplier development. In order to factor China cross-border electricity supplier to find out the impact of development and put forward reasonable proposals for the development of China's cross-border electricity, many scholars have their own methods. Mr. Li and An Liren scholars (2015) on cross-border electricity supplier logistics company carried out a detailed study. The research focused on integrated services enterprise system [1]. Liu Zhen and Wang Mingyu (2014) focused on the problems of the development of cross-border electricity supplier logistics and put forward reasonable proposals [2]. Zou Lei and $\mathrm{Xu} \mathrm{Ce}$ (2015) proposed to promote healthy and rapid development of cross-border electricity supplier's recommendations [3]. Wu Min (2015) proposed under the leadership of the Internet + . Prospects for the development of cross-border electricity supplier are promising [4]. Wang Yu fen (2015) and Li Guan Peng (2015) proposed cross-border electricity supplier should depend on the success of logistics model. The study logistics model is very necessary $[5][6]$.

\section{Game Model of Cross-Border Cooperation of Business Enterprise}

Many Chinese scholars research cross-border electricity supplier development and they are from the theory set forth, most scholars are from the China Statistical Yearbook and literature research to identify cross-border electricity supplier in recent years, the development of data and theoretical analysis and elaborate graphics Finally, scholars have come to China cross-border electricity supplier influence factors and cross-border electricity business development advice. By reading a lot of literature, I think that the main obstacles to cross-border electricity supplier enterprises cooperation and exchanges between countries, the most popular online trading platform is a B2B model, $\mathrm{B} 2 \mathrm{~B}$ model is the premise and basis of $\mathrm{B} 2 \mathrm{C}$ and $\mathrm{O} 2 \mathrm{O}$, inter-enterprise the mutual trade directly determines the fate of the Chinese cross-border electricity supplier. For a good analysis and cooperative relations between enterprises, we use game theory for domestic and foreign enterprises to establish whether the cooperative relationship matrix game, has important practical significance to study Chinese cross-border electricity supplier.

The phenomenon of cross-border electricity supplier in the enterprise is whether cooperation will appear in the various countries, whether corporate body of cooperative game includes participation in cross-border electricity supplier relationship between domestic and foreign enterprises, domestic and foreign government departments. The phenomenon of cross-border electricity supplier is mainly reflected in the successful development of cooperation between enterprises and whether business relationship game, game relationship business and government executives, companies can choose whether cross-border cooperation in the electricity business transactions, the Government, through the phenomenon of the game managers can be cross-border electricity supplier of security and national interests through the game link management system selection. To this end, through the establishment of game analysis between domestic and foreign enterprises can draw the appropriate game theory, easy for people to understand the significance of the game and provide the basis for management manager.

This paper is only on behalf of the company which is willing to trade in international cross-border cooperation in the electricity business enterprises, not including illegal businesses and informal businesses, international companies are the basic assumptions of the company's compliance, according to the different companies in their country, the enterprise the body may be divided into cross-border electricity supplier Chinese enterprises and foreign enterprises are two major cross-border electricity supplier of the basic groups. Chinese cross-border electricity supplier companies have chosen to cross-border electricity supplier cooperation behavior is far greater than the cross-border foreign business enterprise cooperative behavior, because China's development is restricted his country, China's cross-border business enterprise, although more than cooperative behavior behavior of foreign cross-border cooperation of business enterprise, but the behavior of foreign cross-border cooperation of business enterprise for domestic conduct cross-border business enterprise has a corresponding degree of cooperation instead. Choose between enterprises and for each enterprise he has two basic options, namely cooperative or uncooperative behavior. Suppose loyal domestic electricity business venture for the cross-border mA, non-cross-border electricity supplier loyalty foreign cooperative enterprises $\mathrm{mB}$, the largest international trade accommodate degree $\mathrm{n}$, a relationship formula $\mathrm{mA}<\mathrm{n}, \mathrm{mB}<\mathrm{n}, \mathrm{mA}+\mathrm{mB}>\mathrm{n}$, that is, whether domestic or foreign business enterprises which a single main action, the international trade will not saturate, but once the two groups appear simultaneously at international trade will have a saturation phenomenon. $\mathrm{MA}$ and $\mathrm{mB}$ will represent corporate behavior between the two countries, according to a statement on the part of the paper, the two countries established game matrix between enterprises in Table 1 below. 
Cross-border foreign business enterprise $m_{B}$

\author{
Chinese cross-border \\ business enterprise $m_{A}$
}

Cooperation

1000.850
Uncooperative

1500.400
Cooperation

Uncooperative
10.1200
5.40

The two game matrix enterprise groups between customary meaning paid as follows: 1) When the two main groups of companies have chosen to cooperate in cross-border electricity supplier in behavior, mA cooperative groups accustomed to pay for the $1000, \mathrm{mB}$ for groups used to working to pay for the $850, \mathrm{mB} \mathrm{mA}$ community groups to pay more than the habit less reason for this is because it is customary for cooperation, $\mathrm{mB}$ population less than $\mathrm{mA}$ active population, so there are differences on the value; 2) When mA select group of cross-border electricity supplier cooperation $\mathrm{mB}$ groups think they get less interest when such groups choose not cooperate, international trade does not saturate, thus $\mathrm{mA}$ customary payment groups will increase to 1500 , and $\mathrm{mB}$ groups because there is no cooperation, therefore $\mathrm{mB}$ customary payment group will be reduced to 400; 3) Similarly, when the cross-border electricity supplier group selection $\mathrm{mA}$ and $\mathrm{mB}$ uncooperative behavior when selecting group cooperation, international trade is not a conflict of interest, $\mathrm{mB}$ groups who co-habit so pay increase, increased from 850 - 1200, and mA because the groups are keen to cooperate but did not achieve their goals, so accustomed to pay a larger decline, thus reduced to $1 / 100$ of 1000 , used to pay becomes 10 ; 4) When $\mathrm{mA}$ and $\mathrm{mB}$ population groups have chosen to cross-border cooperation in the electricity business behavior, as both a conflict of interest will not produce optimal satisfaction, so the diet will reduce the payments, population reduced to $5 \mathrm{~mA}$, and $\mathrm{mB}$ population decrease 40 .

After the above statements, the game of cross-border cooperation between the electricity supplier companies can be called dominant balanced game, choose the dominant strategy is the best choice for each player of the paper, cross-border electricity supplier cooperation customary behavior is comparison of the two groups preferred choice for $\mathrm{mA}$ groups, the group if they choose to cooperate regardless of $\mathrm{mB}, \mathrm{mA}$ cooperative groups accustomed to pay much more than uncooperative payment habits, so domestic and cross-border electricity supplier cooperation choice for groups $\mathrm{mA}$ is a dominant strategy, the same for $\mathrm{mB}$ groups, the group chose to work regardless of $\mathrm{mA}$ in international trade or not, $\mathrm{mB}$ groups accustomed to pay much more than the habit of cooperation pay uncooperative, so trade cooperation Select groups for $\mathrm{mB}$ is also a dominant strategy, namely cross-border cooperation is the dominant electricity supplier balanced game two major groups, so that both benefit. It can be shown that, in the case between Governments without limitation, whether domestic or foreign joint venture companies will adopt the habit of cooperation and hinder the cross-border electricity supplier inevitable factors, in order to make cross-border electricity supplier cooperation order normalization, there must be between the government and enterprises mature trading platform added governance in order to ease international trade conflicts of interest phenomenon.

\section{Fuzzy Comprehensive Evaluation of Cross-Border Electricity Supplier Logistics}

Chinese cross-border electricity supplier affects by many factors, here we use the analysis method of fuzzy mathematics, fuzzy mathematical analysis method is suitable for the blur, blur phenomenon is encountered difficulty many scholars now, there is no data for the phenomenon has only explained the theory it is not enough, it is for telling ability is flawed, this paper take fuzzy mathematical method for the analysis of Chinese cross-border electricity supplier factors are well studied. Figure 1 shows a fuzzy judgment three Chinese cross-border electricity supplier influencing factors:

Figure 1 shows that China's cross-border electricity supplier assessment factors can be divided into four aspects, first is the logistics links, cross-border electricity supplier in the trading process is very important link in the logistics, logistics cost determines the cross whether electricity suppliers can be earned throughout the selected mode of transportation determines arrive track speed of other countries, logistics information to provide protection for the security of cargo. In product sales, customer focus lies in the quality and variety of products to 
provide customers with after-sales service guarantee. Government investment in cross-border electricity supplier development plays a vital role in funds to pay for online trading platform. The buyer and seller are important factors. After the actual investigation of the experimental program took 100 logistics students conducted a survey, for each part of the index gave a clear weight results are as follows.

Chinese cross-border electricity supplier index weight of factors influences a weight of $A=(0.4,0.3,0.1,0.2)$, two indicators weight of $\mathrm{A}_{1}=(0.4,0.4,0.2), \mathrm{A}_{2}=(0.5,0.3,0.2), \mathrm{A}_{3}=(0.4,0.1,0.5), \mathrm{A}_{4}=(0.3,0.4,0.3)$, the survey results as well as the right of each index weight as shown in Table 2.

Take synthesis algorithm, the results are as follows:

$$
\mathrm{B}_{1}=\mathrm{A}_{1} * \mathrm{R}_{1}=(0.4,0.4,0.2,0.1,0.1) ; \mathrm{B}_{2}=\mathrm{A}_{2} * \mathrm{R}_{2}=(0.2,0.25,0.3,0.3,0.1) \text {; }
$$

$\mathrm{B}_{3}=\mathrm{A}_{3} * \mathrm{R}_{3}=(0.2,0.4,0.4,0.2,0.1) ; \mathrm{B}_{4}=\mathrm{A}_{4} * \mathrm{R}_{4}=(0.3,0.2,0.3,0.2,0.2) ;$

$\mathrm{B}=\mathrm{A} * \mathrm{R}=(0.4,0.4,0.3,0.3,0.2)$; Considering Description Chinese cross-border electricity supplier is in good development, cross-border electricity supplier China described space as well as forward.

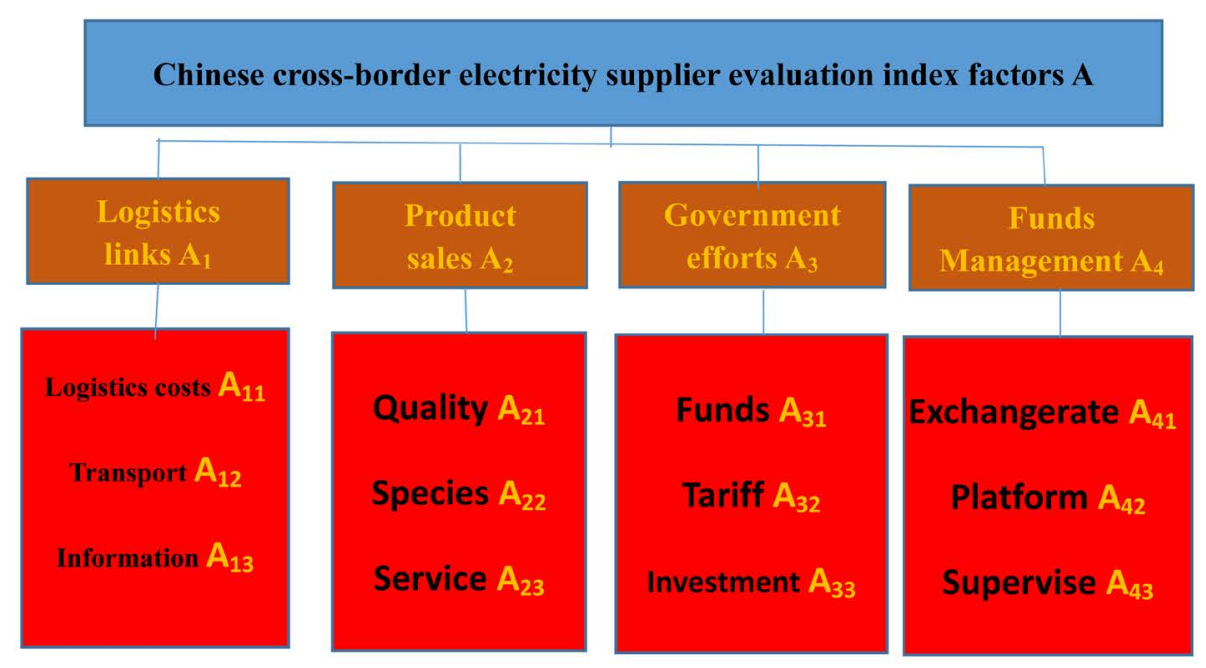

Figure 1. China cross-border electricity supplier influencing factors.

Table 2. China cross-border electricity supplier factors index system.

\begin{tabular}{|c|c|c|c|c|c|c|}
\hline \multirow{2}{*}{ Level indicators } & \multirow{2}{*}{ Secondary indicators } & \multicolumn{5}{|c|}{ Evaluation } \\
\hline & & excellent & good & general & Poor & error \\
\hline \multirow{3}{*}{ Logistics links $A_{1}$} & $\mathrm{~A}_{11}$ & 0.3 & 0.5 & 0.1 & 0.1 & 0 \\
\hline & $\mathrm{A}_{12}$ & 0.4 & 0.3 & 0.2 & 0.1 & 0 \\
\hline & $\mathrm{A}_{13}$ & 0.5 & 0.3 & 0.05 & 0.05 & 0.1 \\
\hline \multirow{3}{*}{ Product sales $\mathbf{A}_{2}$} & $\mathrm{~A}_{21}$ & 0.1 & 0.2 & 0.3 & 0.3 & 0.1 \\
\hline & $\mathrm{A}_{22}$ & 0.05 & 0.25 & 0.4 & 0.2 & 0.1 \\
\hline & $\mathrm{A}_{23}$ & 0.3 & 0.2 & 0.3 & 0.2 & 0 \\
\hline \multirow{3}{*}{ Government efforts $\mathbf{A}_{3}$} & $\mathrm{~A}_{31}$ & 0.2 & 0.5 & 0.3 & 0 & 0 \\
\hline & $\mathrm{A}_{32}$ & 0.1 & 0.4 & 0.3 & 0.2 & 0 \\
\hline & $\mathrm{A}_{33}$ & 0.1 & 0.2 & 0.4 & 0.2 & 0.1 \\
\hline \multirow{3}{*}{ Funds Management $\mathbf{A}_{4}$} & $\mathrm{~A}_{41}$ & 0.2 & 0.1 & 0.3 & 0.2 & 0.2 \\
\hline & $\mathrm{A}_{42}$ & 0.3 & 0.2 & 0.3 & 0.2 & 0 \\
\hline & $\mathrm{A}_{43}$ & 0.1 & 0.2 & 0.5 & 0.05 & 0.15 \\
\hline
\end{tabular}




\section{Conclusion}

Game Theory can clearly analyze the need for cross-border electricity supplier logistics generated. It can make reliable recommendations for the development of China's cross-border electricity supplier logistics. It can also analyze the status quo of cross-border electricity supplier logistics. Cross-border electricity supplier development is an important way to promote the circulation of commodities between countries in the process of commodity circulation that can be shared between the interests of all countries, and each country can improve their networking technology. Under the new era, China should seize the opportunities and challenges, China's import and export trade in the first part of the world. China should make full use of B2B Internet trading platform. Chinese enterprises should be mature in B2B model, the first enterprise to their products quality improvement, which is a prerequisite for consumers to buy Chinese products. Secondly, companies should open their products visibility, so that more foreign consumers know their products and ideas. And finally, the Chinese government should increase investment in China cross-border electricity suppliers of investment, and overseas investment positions are the most important content.

\section{References}

[1] Li, X.D. and An, L.R. (2015) Cross-Border Electricity Supplier Logistics Companies a Comprehensive Service System and Empirical Study. Chinese Economic Circulation, 11, 49-57.

[2] Liu, Z. and Wang, M.Y. (2014) Cross-Border Electricity Supplier Situation Analysis and Trend. E-Commerce, 2, 9-10.

[3] Zou, L. and Xu, C. (2015) Promoting Cross-Border Electricity Business Healthy and Rapid Development. Macroeconomic Management, 12, 33-36.

[4] Wu, M. (2015) Under Horizon Cross-Border Electricity Supplier Ecosystem to Analysis. Commercial Economic Research, 34, 75-76.

[5] Wang, Y.F. (2015) A Comparative Study of Cross-Border E-Commerce Logistics Model. Chinese Trade Tribune, 29, 20-21.

[6] Li, G.P. (2015) Electricity Supplier Logistics—-The World at Your Fingertips. Continental Bridge Perspective, 9, 3537.

\section{Submit or recommend next manuscript to SCIRP and we will provide best service for you:}

Accepting pre-submission inquiries through Email, Facebook, LinkedIn, Twitter, etc.

A wide selection of journals (inclusive of 9 subjects, more than 200 journals)

Providing 24-hour high-quality service

User-friendly online submission system

Fair and swift peer-review system

Efficient typesetting and proofreading procedure

Display of the result of downloads and visits, as well as the number of cited articles

Maximum dissemination of your research work

Submit your manuscript at: http://papersubmission.scirp.org/ 